\title{
Trans-Screens of Gender and Jewishness in Jill Soloway's Transparent: Post-Network TV and the Screendance Scene
}

Hannah Schwadron, Florida State University

\begin{abstract}
This essay analyzes the artful insertion of screendance scenes in Season Two of Jill Soloway's Amazon hit, Transparent (2014- ), highlighting how bodies and camera choreograph affective connections core to the plot in this televisual portrait of a Jewish American family. In doing so, I underscore a layered screenic trans-ness that conjoins circular manipulations of time and bodily action to overlay transgender and transhistorical experiences as co-constitutive themes.
\end{abstract}

Keywords: Trans-Screens, Transgenerational, Transhistorical, Gender, American Jewishness, Post-Network TV

How does the TV portrait of a lovably strained Jewish family endear audiences to transgender narratives, and what do artful screendance aesthetics, such as filming in the round have to do with it? This essay's critical discussion of Jill Soloway's hit series Transparent (Amazon Prime 2014-present) follows this line of questioning. In doing so, I champion the show's contributions to pop cultural representations of ethnic and sexual diversity through highlighting the use of non-verbal communication and camera choreography. In what follows, I offer a close reading of two movement-driven scenes, and draw from that analysis a framework for thinking about the affective integration of screendance aesthetics in the popular televisual realm. In both of the scenes I discuss, dance becomes the expressive mode by which characters access the bodily effects of traumas carried over from past generations, and through which audiences witness characters experiencing their present-day bodies in especially painful ways.

In looking at the aestheticization of Transparent's narrative content through screendance scenes, it becomes clear how the circular compositions of body and camera manifest an emancipatory embrace of the show's Jewish and transgender storylines. I argue that this collaborating bodily and camera choreography works to conjoin ethnic and sexual identities as overlapping circles. My analysis honors the difficult work of rendering marginalized bodies legible in the popular realm while considering the limits of such shared representation for groups in varying stages of mainstream acceptance and assimilation. Finally, I discuss this point in relation to the recent ousting of lead actor, Jeffrey Tambor, after allegations of his harassment of two 
transwomen on set. In analyzing the show in this way, my aim is to underscore the representational stakes of Transparent's movement aesthetics while addressing the minoritarian discourses and experiences they circumscribe on and off set.

First, I situate the emergence of screendance on television as part of a broader postnetwork phenomenon. In broad terms, post-network TV can be defined as the current period of watching television that allows us more individuated control than ever. ${ }^{1}$ This increased access and control has accompanied ever more diversification of programming, which has allowed TV to be edgier and more oppositional in content. As television scholar Nick Marx has pointed out, this has resulted in shows that are more "inviting" in scope, offering possibilities for marginalized cultural identities to be seen on-screen and courted as viewers. ${ }^{2}$ These are edgy and inclusive attributes for which Transparent has been celebrated. For one, Amazon's wildly popular dramatic comedy has more transgender and gender-nonconforming people-thirty-six employees in total -in its cast and crew than any other show in television history. ${ }^{3}$ Moreover, the show is widely heralded for its social justice content, as well as the way it delivers this content through especially artful means. ${ }^{4}$

It is within this context that a screendance look and feel, here referring to a broad array of cinematic techniques and 'dancerly' sensibilities often reserved for galleries and screendance festivals, now makes its way onto narrative TV, where niche viewers can find a growing number of shows that speak to special interest or subcultural topics like Transparent. This assimilation of especially artful cinematic qualities helps a show like Transparent accompany its often darkly funny material with emotional depth and movement-driven metaphor. It also brings high art aesthetics into the popular realm. In this adoption of screendance for TV, Soloway and her creative team deliver powerful social messages through high art dramatizations of social justice themes. The show's huge success in number and scope of awards suggests a wide-spread appreciation of such creative tactics. ${ }^{5}$

Importantly, attention to crafting the movement of the actors was always a priority in Transparent's pre-production creative approach. Soloway and the cast worked with Los Angeles directing coach Joan Scheckel in early iterations of the rehearsal process to explore elements of non-verbal communication. For example, actors were asked to move towards those to whom their characters felt closer, and away from those they felt farther from emotionally. ${ }^{6}$ Such open-ended exploration is known to be fundamental to Soloway's directorial style and is especially exciting for cast members who regularly talk about Soloway's feminist, egalitarian approach and her mode of honoring the artistic choices made by cast members. ${ }^{7}$ Soloway herself joined in these family role plays, enacting encounters no doubt familiar to her as she drew movement inspiration from a show loosely based on her own Jewish father's transgender coming out. It is significant to note that the cast regularly described the dynamics on set through familial terms. For example, Actor Jay Duplass who plays the middle brother Josh described his 
first screen test with co-stars Amy Landecker and Gaby Hoffman "who are not only my sisters on a TV show but my sisters in real life now" as "kind of magic." ${ }^{8}$ No doubt this is why the allegations of Tabor's violence in the fall of 2017 was so personal for the cast, causing Duplass to describe the situation as "traumatic." ${ }^{9}$ In this slide between actor and character dynamics and their enactment through movement and affect on and off camera, it is helpful to foreground the family-style ethos that also link an analysis of screendance scenes to the real-life traumas they encircle.

\section{Ethno-Sexual Inheritance and the Dancing Circles of Jewish Trans-ness}

Within the world of Transparent's Pfefferman family, individual and collective experiences of trauma extend beyond the time and place in which the characters live. A central component of the show is the depiction of intersecting Jewish, gender, and sexual identities that carry across multiple generations to account for past traumas, or what I will call "ethno-sexual inheritance." This ethno-sexual inheritance is manifest for every current-day Pfefferman family member, albeit in different ways. Father Mort is transitioning to "Mapa" Maura, Mother Shelly is finding her voice after early abuse by a school teacher, Eldest daughter Sarah, middle son Josh, and youngest daughter Ali deal with various character crises that dial back to sexual dysmorphias informed by traumatic events they lived, as well as those they inherited. As each pursues their individual journey of self-reconciliation, a larger communal circle of acceptance from current day community and ghostly past figures continually embraces them all.

Transparent yokes transgenerational, transhistorical frames to transgender ones as current-day characters come to know themselves through what they find out about transgender members of their Jewish family's past. It is this central relationship, which I'm calling the "Jewish-trans-ness" of the show, that continues to unfold through transgenerational family inheritances and a growing number of transgender characters and plotlines across four seasons and counting. In the scenes I describe below, dance and camera choreographies physicalize this core relationship between trans subjects. Filmed as movements of memory in Transparent's second season, I argue that these screendance scenes should be seen as "trans-screens" insofar as they interrelate identity, inheritance, and embodiment through dance and a dancing camera, despite the absence of any choreographer or movement director in the credit roll. They offer artful layering of ethno-sexual identities as the show's Venn diagram of Jewish and transgender demographics, and do so through body and camera techniques which both resonate with and help construct the circular themes of the narrative content.

Soloway's trans-screens aestheticize the diachronic blurring of past and present realities to elicit empathetic response around the show's "epigenetic" subject matter. The premise of epigenetics in these scenes and as a field of genetic study is that bodies hold and can access histories beyond their own lifetimes. Similarly, bodily movement carries 
layered meaning beyond what is said, and even beyond what may be consciously intended. Simply put, epigenetics concerns itself with how genetic inheritance influences lived experiences. The understanding is that traumatic events in our family's lives persist in our bodies, blood, and bones, leaving molecular scars that adhere to our DNA. ${ }^{10}$ Leading researchers in epigenetics and dance artists alike suggest that addressing those scars can help us heal at the level of the body. ${ }^{11}$ In Transparent's transscreen scenes, I find this enactment of past trauma through bodily movement and movement of the camera especially significant. Body and camera act as co-constituting elements of the individual and collective subject in need of healing.

In the first example I will analyze from Season 2, Episode 1, the screendance scene is structured as a flashback. The juxtaposition of time periods is made possible by a quick camera cut that moves from a present-day wedding party scene to a festive ball at the historic Institute of Sexuality in Berlin, wherein the action of a central dancing figure encircled by communal joy continues in the foreground of both shots. The second example of a trans-screen scene from Season 2, Episode 9 utilizes a group campfire as a core mechanism through which characters make contact across generations and contexts. A present-day forest gathering morphs into a figment of feelings and imagination. This second trans-screen scene is less a conjoining of dancing scenes as in the first example, and more of an imaginative fantasy, or what we might think of as epigenetic illusion. In this scene, the prospect of past traumas inherited through the body come to life as if they were happening in a time neither past nor present, but one that only exists in the realm of emotions.

Season 2, Episode 1 takes place at the lesbian wedding of eldest daughter Sarah, which is nulled as soon as the party ends. Sarah realizes midway through the reception that she is not ready to leave her ex-husband and life with her kids. The moment hits her hard in the bathroom stall where she forces her siblings to help process what to do while she panics and pees. But before this abrupt confession, the festive event is in full swing. Dressed all in white, the family and friends dance the quintessential wedding Horah to the live accompaniment of singer Ayana Haviv and attending klezmer band. The mood is big-spirited and convincingly human, if also exaggerated to create a sense of the heightened and often frenetic energy that accompanies weddings. ${ }^{12}$ Hands clasped tightly and arms raised overhead, they complete the marriage with a cultural dance that all on set appear to know well. The camera traces the inside of the dancing circle, panning over their faces as characters commune in ritual tradition, straining to talk over the music. 


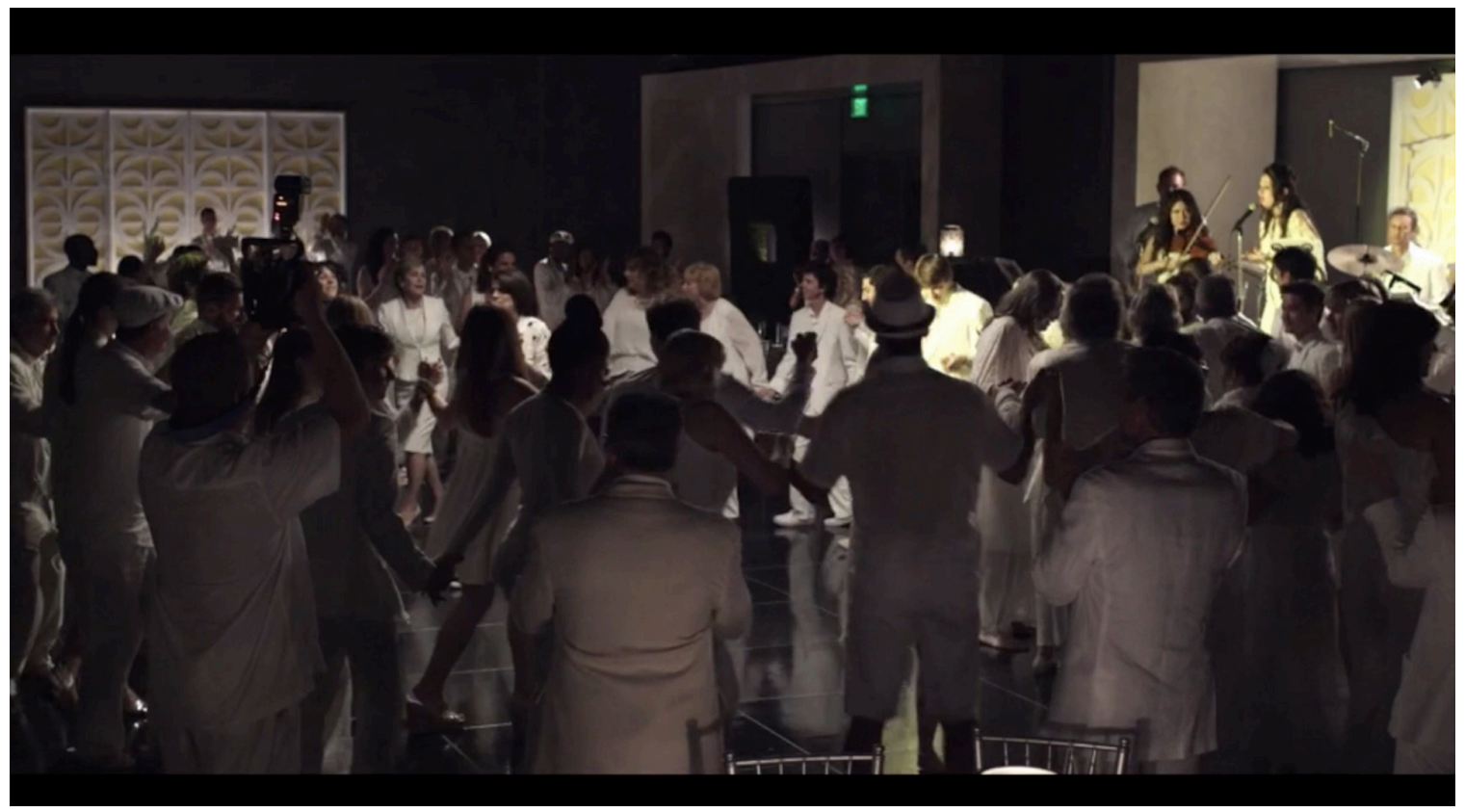

The wedding Horah in full swing. Screenshot taken by the author.

Cousin Simon (Bashir Naim) enters the center of the shot and the symbolic ring, gazing upward. His long steps emphasize the downbeat, and his gait slows against the sustained speed of the crowd. The community bounces their grapevine to the right, holding him in his moment, and his hips sway side-to-side with iconic flamboyance. Closing his eyes, he travels inward, driven into a trance by the immersive energy and sound. He lifts his chest to the sky and tears off his white suit jacket, swinging it in lassoing circles overhead. The rotations of the jacket wind time backwards, a transhistorical move, and a quick cut takes the viewer to a queer costumed ball in Weimar Berlin. A tight shot closes in on a male dancer (while the face is out of focus, it is likely also Naim) who picks up where Cousin Simon left off. The frame moves from his undulating wrist to the full party scene. 


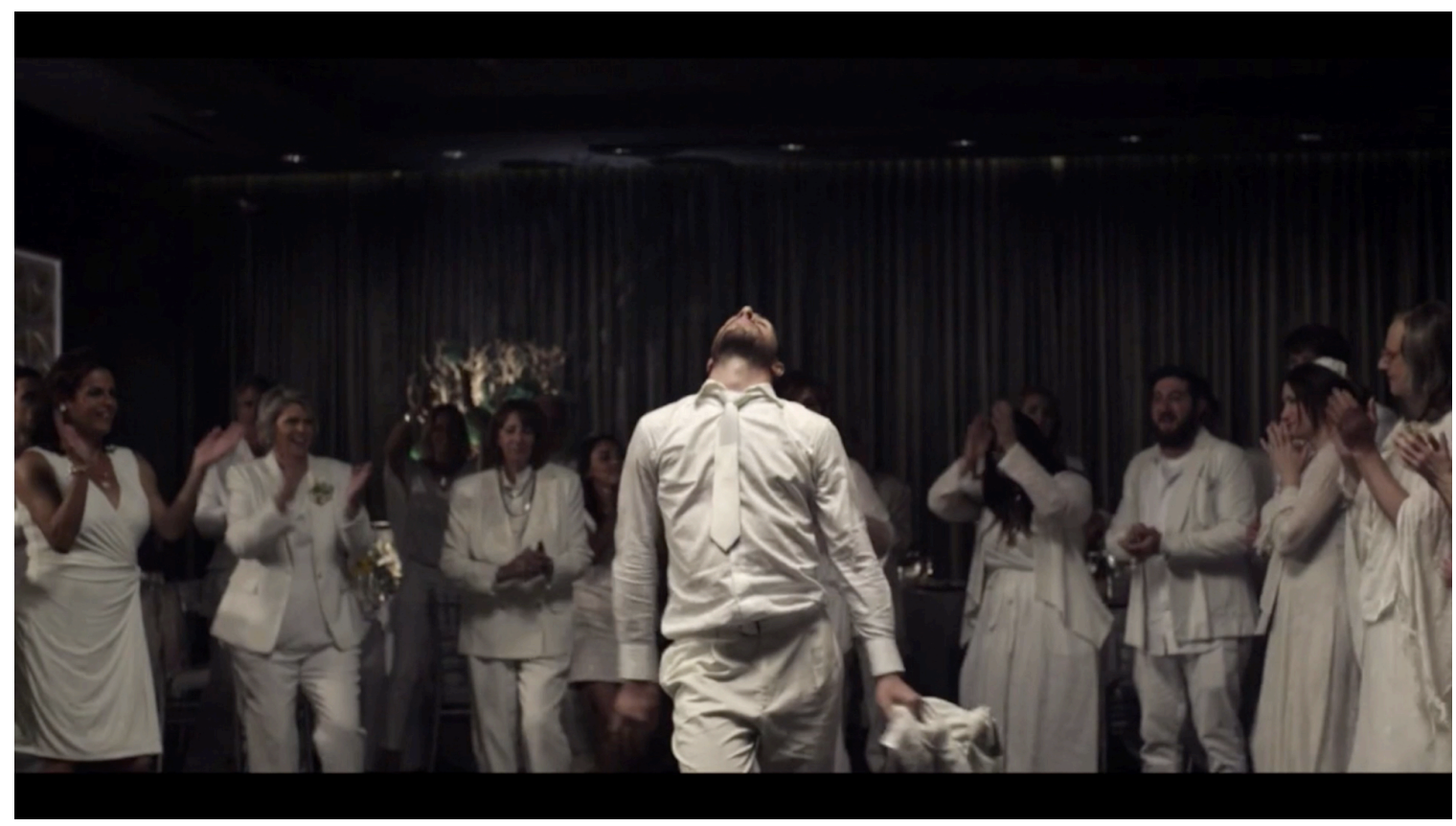

Cousin Simon (Bashir Naim) dances in the middle of the Horah scene. Screenshot taken by the author.

The camera introduces a glitzy mix of dancing bodies and animated faces we haven't yet met; a bare-chested sailor, a flapper pianist, a lounging male femme fanning off. And for the duration of the scene, there is only joy. Costumed people dance alone and in groups, as lavish boas and lingerie accent impromptu high kicks and conga lines. Silk and feathers combine period party dress and draped finery to outfit a full room of individuated style. Transgender actor-model Hari Nef, who we soon learn plays Tante (Aunt) Gittel, appears on camera for the first time as a teenaged beauty, wearing a deep red velvet cape over a low-cut green dress. When we meet her, the regal fabric has just whipped into extravagant rotation to spin the camera with the same circular force. The royal figure greets her dance partner's nipples first as if every dance might start this way, and the infectious smiles filling every frame suggest that somehow they do. 


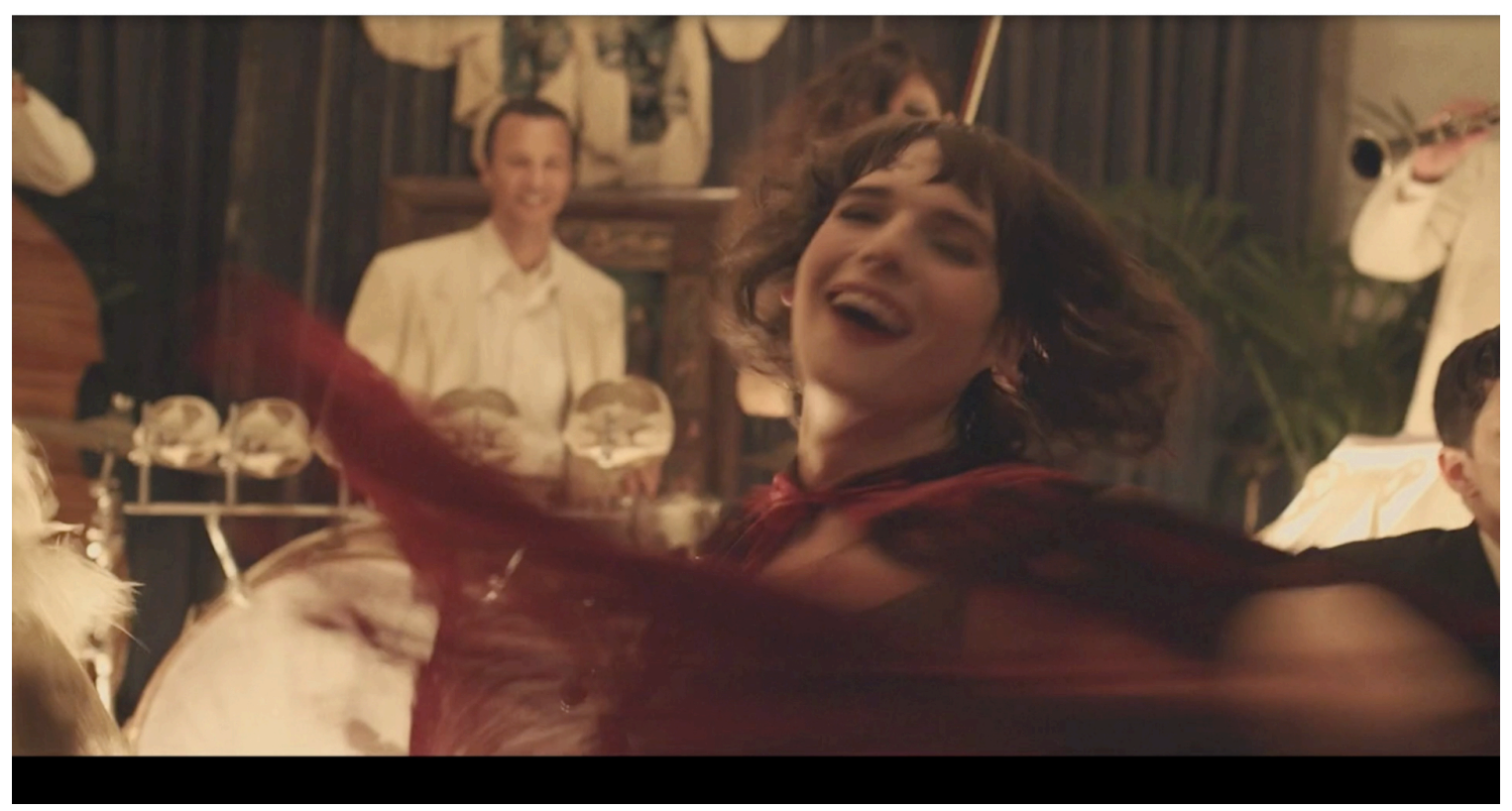

Gittel (Hari Nef) whips her velvet cape in a flashback to 1933 Berlin. Screenshot taken by the author.

The 1933 Berlin flashback shows the cosmopolitan city's flourishing gay subculture before the Nazis destroyed it and the people who populated it. ${ }^{13}$ The scene takes place in a historical reconstruction of the Institute on Sexual Science, an elaborate villa of gender non-conforming people who lived and worked alongside Magnus Hirschfeld, founding researcher known as the "Freud of transvestite understanding" during the Weimar period. ${ }^{14}$ The party scene sparkles with bohemian decadence and glamorous abandon and the bodily and camera action create an atmosphere that is free and unabashed, consistent with historical images and accounts of the period. This fairly unfamiliar depiction of German life before the Holocaust connects Jewish and transgender subjects and experiences for the first time on American television, and its screendance depiction brings the safe circle of the Institute into the foreground.

When, in Episode 9, Nazi-era soldiers drag Gittel violently into the woods at a presentday campfire turned transhistorical book burning, the festive circles of Jewish lesbian wedding dances and queer balls are broken by a terrorizing raid that also makes use of the circular theme. Like in Episode 1, this second screendance scene also results from an emotional trigger, this time just after a horrible moment for Maura and Ali at the Idyllwild Wimmin's Festival. Despite going to the festival to join cadres of liberated women (in theory, a protective circle of acceptance), Maura and Ali deal with the discriminatory and exclusionary ethos of feminist purists who reject Maura on the basis of her having been born male. They force her to leave by screaming the episode's title: "Man on the Land!" The intense moment of rejection recalls the violent past, where Hirschfeld's institute was sieged and his papers and library collection burned. 
The scene starts as youngest daughter Ali (Gaby Hoffman) enters from out of frame. Her eyes are bloodshot from crying and still outlined in the dotted faux tribal decoration from an earlier visit to Shaman Crying Bear's Intention Circle, where a white New Yorker feigns connection to indigenous rituals. Despite the humorous juxtaposition of Ali's face makeup against her evident emotional fatigue, the tone has shifted drastically from such sardonic parodies of the festival feel to a flashback sequence that she imagines. Nazi horns blow and a violinist still dressed from the party plays in time with the instrumentation of Alice Boeman's tender ballad "Waiting," but the sound is from elsewhere, imposed upon the scene. A repeating soundtrack from the end of Season 2, Episode 1, the song carries a circular tie back to the previously described scene, as if a theme song for Ali's newfound access to Gittel. Aching variations of bound tension and release present duets of aggression and affect that punctuate the melancholic female voice, which is neither Ali's nor Gittel's, but somehow both. Teenaged Gittel stands by, face and body hung heavy as she watches a friend get pulled from behind by a figure in white button-down shirt and black tie, the same clothing worn by Hitler Youth in the Institute raid.

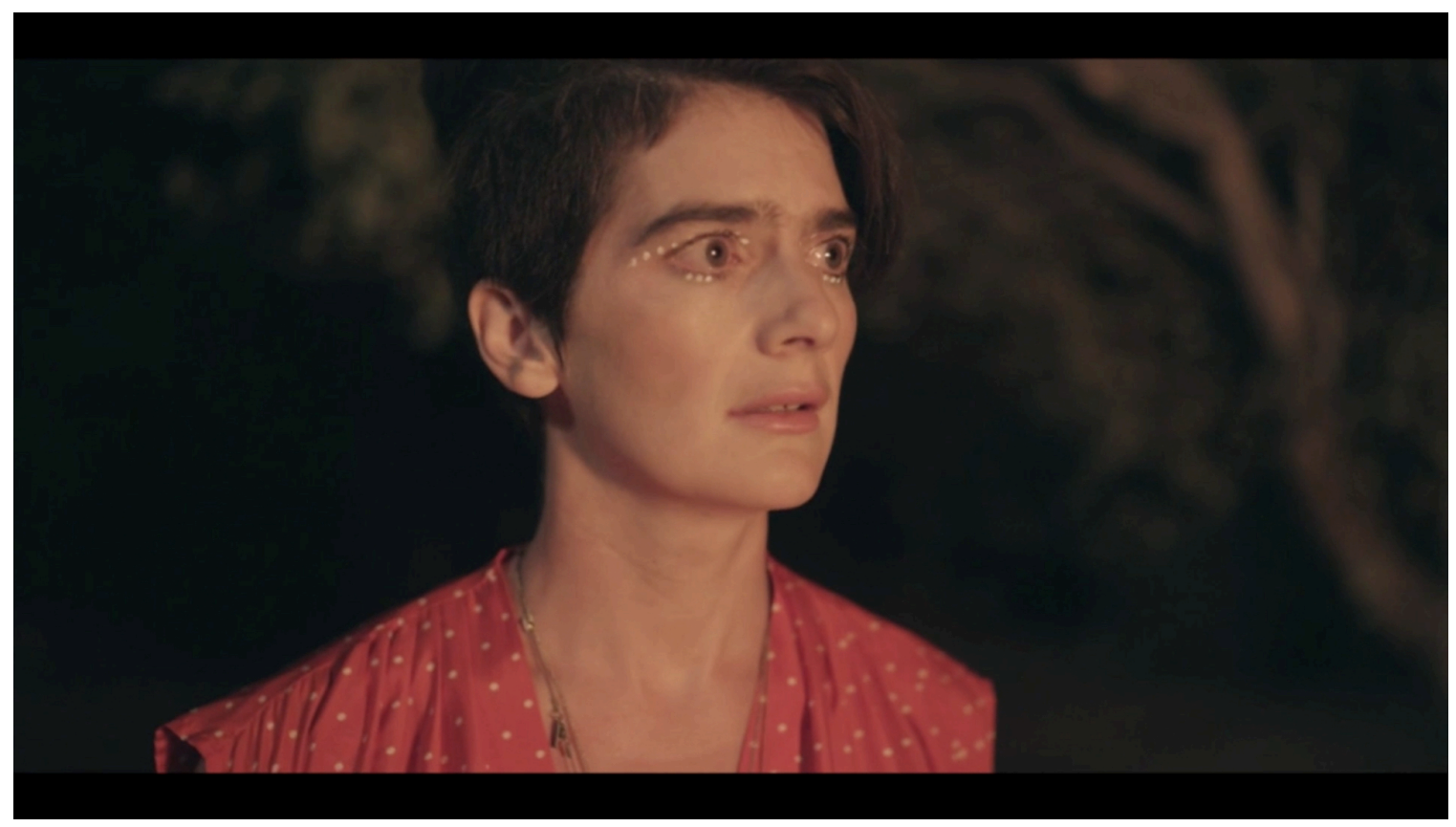

Ali (Gaby Hoffman) enters the fire scene, eyes bloodshot and adorned with white paint. Screenshot taken by the author.

The next image re-costumes these men in full Nazi uniforms, as two yank the necks of more friends from the earlier party scene away from the fire. The camera then comes from behind one such duet, framing their failed struggle to muscle free from the state's stronghold. The moving lens lets us look around the fire at the pained expressions of Institute musicians and dancers alongside unknown men in suits who people the fire's perimeter with eerily hardened facial expressions. Consecutive figures are strangled 
from the back, fighting to loosen limbs from death's grip, which the camera mostly shoots from below, catching the action from a vantage point very close to the center fire pit.

This theater in-the-round continues as the camera partners Ali's solemn transhistorical walk along the circle's edge. She finds her grandmother as a young girl (played by actress Emily Robinson who doubles as Ali's younger self in a previous episode), and the two stand in the flickering light cast by the center flame, holding hands. When the camera moves back to Gittel, crying, two soldiers restrain her arms from the back. A handheld camera then follows her as she falls, traveling down the length of her legs and beige character heels to a pile of strewn books littering the dirt floor. Gittel wrestles against the control until she is carried out of view.

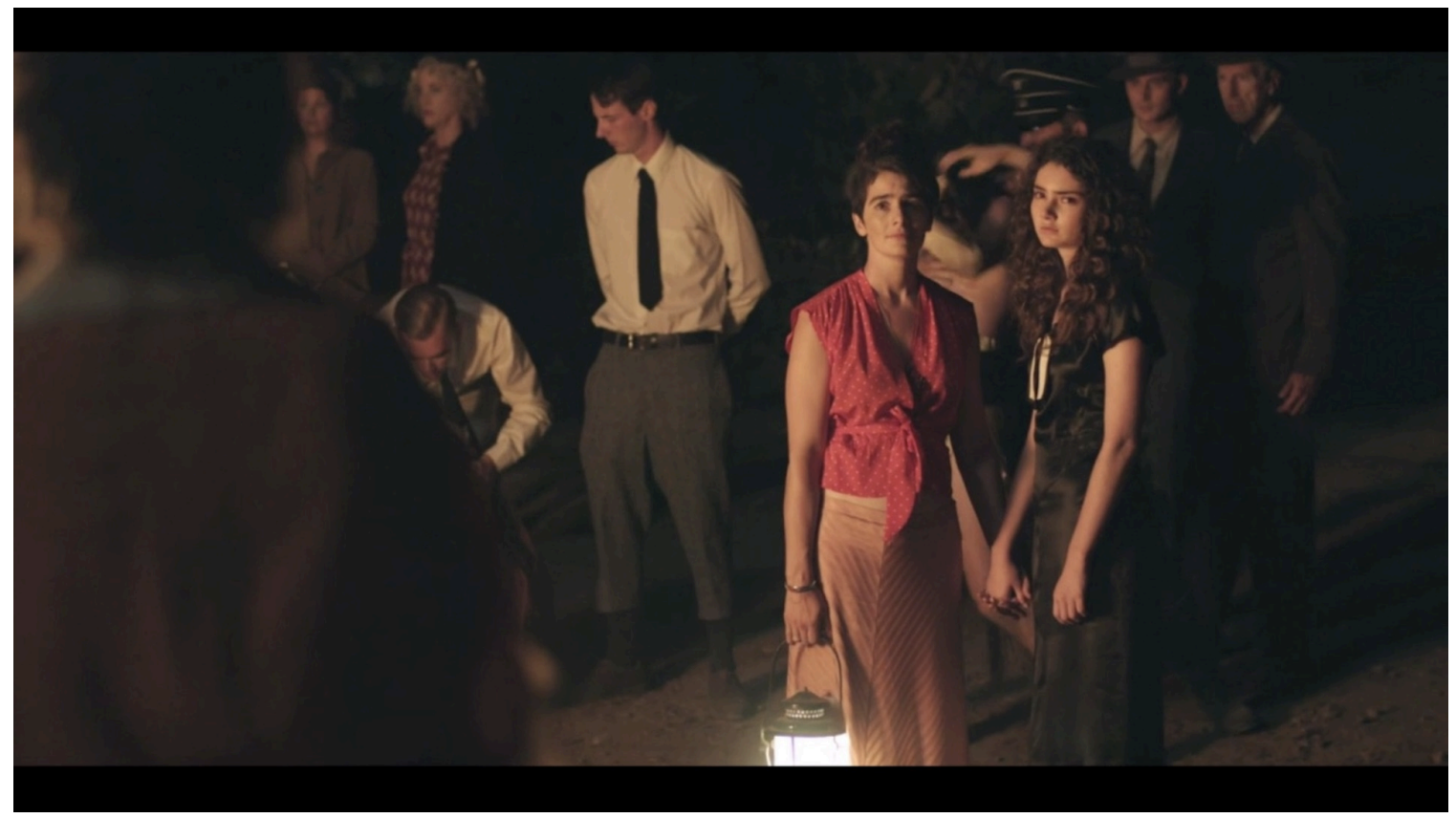

Ali and young Grandma Rose hold hands as they look toward Gittel. Screenshot taken by the author.

The scene's collapse of temporal boundaries around then and now imagines transgenerational bodily trauma as an epigenetic inheritance and choreographic movement sequence of terror and loss. As Ali's anguished expression lingers on-screen at the end of scene, the possibility of self-identification beyond her lived experience is, for these non-verbal moments on camera, both felt and seen. Like the extra-diegetic soundtrack's deafening effect, the scene instills a dizzying sense of characters that can't speak to each other. A waking dream of isolation and despair in the midst of a purportedly pro-women festival, the broken circle of the fireside scene frames the visceral experience of exclusion that drives the episode. 
In both Episodes 1 and 9, screendance scenes appear as filmic reveries, deploying dance and camera techniques to create trance-like states for individual figures and trans-like states for larger compositions of screenic bodies. Conjuring the past to explicate the present, both scenes use circular placements of bodies and camera pathways to deliver intense joy or pain. The first example does the former, flashing from a joyful Jewish wedding dance to a liberated queer Berlin in the 1930s. The second scene is a chimeric choreography of painful present-day harassment and harm, where the embodied encounter between characters and the ghosts of family members is a haunting return; not of monsters, but of the monstrous ways they were mistreated.

The work of the camera in these scenes choreographs rather than merely captures the affective connections unfolding in the plotline. ${ }^{15}$ And it does so through the blending of screendance modes with iconic Jewish ones. Micro-choreographies of the face and hands show feeling in ways that invoke screendance techniques of intimacy and expressivity. ${ }^{16}$ These tight shots also highlight the depth of ethnic connection animated in Jewish circular folk dances, where images of interlocked hands, shared smiles, and cross-circle gazing upon one another, exemplify the spirited nature of dancing together. Moreover, tight shots of the legs and feet convey details of the dancing that anchor the viewer in a literal and figurative understanding of weight. Heavy heels strike the floor with a rhythmic bounce as all on-camera dance the Horah's grapevine pattern. The focus on the step orients the viewer to the gravity of the movement, while also offering a choreographic metaphor of the collective weight of group identity.

Taken together, the bodily positioning of the characters and cameraperson establish circularity from the inside, allowing viewers to witness the action of bodies moving toward the center or pulled beyond the periphery. In other moments, the camera mimics the rotational action of body parts such as a wrist movement or the swirl of costumed fabrics, like Cousin Simon's cape that whipped through the air and into the past. In all cases, both body and camera traverse the space, which viewers take in from 360-degree views. The approach invites the audience to experience the dancing figures as if they were dancing along rather than watching a proscenium-styled documentation oriented towards a frontal plane. Furthermore, tight shots on faces, body parts, and contact points in which bodies across the circle are in view encourage a sense of being present in the space and the experience, which work with the especially festive or sorrowful soundscape to enhance the probability of kinesthetic empathy in the viewer. ${ }^{17}$

While circles are a repeating motif, the dancing bodies and dancing camera operate differently in each of these scenes. Deploying unique techniques of transhistorical juxtaposition, these scenes make symbolic use of circular themes that break with linear time and progression. Though proceeding in clear seasonal and episode sequence, these trans-screens extend the storyline while interrupting any chronological view of events. In this sense, the scenes offer important echoes of each other. As paired dances 
that rely on their cumulative power, they act as both narrative and affective devices that help drive the plot forward only to circle back and around. This circular theme informs the staging of bodies on screen as well as the camera techniques deployed to depict them. This compositional strategy represents and aestheticizes the biological and chosen family circle, the relationship to Jewish tradition through actual circle dances, the rounded relationship to time that suggests the cyclical movement of memory, the transitory aspects of identities in motion, and the epigenetics of trauma that return again and again with each new generation.

\section{Trans-face Embodiments and the Limits of Representation}

Transparent's huge success among U.S audiences exemplifies the ever-expanding embrace of niche programming on post-network TV that continues to stretch the boundaries of what and who can appear on screen. The show has won major gains for its representational politics, and the ways it showcases the humanity of transgender subjects either excluded from televisual subject matter or too often depicted as sex workers without a history worth remembering and without family support. ${ }^{18}$ Important too is the show's extension of the more familiar Jewish family portrait to include transgender subjects and experiences, which offers much needed revisions to the typical scripts of a heteronormative family whose aim is acculturation. ${ }^{19}$

Still, this well-intentioned circle drawn around Jewish and transgender identities deserves more critical attention. In depicting a layered "trans" frame that draws together themes of Jewish identity, family inheritance, and gender and sexual liberation, the show takes liberties to partner oppressed groups and histories with unequal histories; that is, as if they were equivalent, when they are not. Transparent's Second Season does so primarily through the inspiration of Magnus Hirschfeld, who was targeted by the Nazi party as a Jewish transsexual rights advocate. This is significant to note when understanding the ways that Season Two's screendance scenes reference especially legible Jewish American material, that is, the Jewish wedding and the Holocaust. Decades of popular media portrayals (think Fiddler on the Roof and Schindler's List) have created a broad audience familiarity with these Jewish contexts. In what I am arguing here, the visceral intensity of feeling that accompanies both Jewish wedding and Holocaust representations works to make it possible for audiences less familiar with transgender experiences and storylines to see and accept transgender identities on TV. In doing so, these screendance scenes create the affective conditions for viewers who understand Jewishness as always already abject, to also understand Jewish family trauma as a way to embrace other marginal identities less represented in the mainstream.

In addition to winning audiences across liberal post-network niches, Jewish insideroutsider tropes humanize abject experiences that the Jewish body has come to 
represent. In turn, transgender tropes reaffirm the openness of Jewish progressive discourse. When it comes to the history of Jewish pop cultural presentations, however, transgender subjects extend and revise a legacy of Jewish American corporeal representation that centers on the effeminate Jewish male. The most beloved Jewish figures in American television have been Woody Allen-esque schlemiels and viewed as such. In Transparent's cast of characters, however, many are women by birth or by choice, and a core aspect of the show appears to be the celebratory destabilization and reconfiguration of this longstanding masculine femme trope for both male and female Jewish characters. Refreshingly, transgender characters appear the most self-actualized of all. And yet, the show revolves around its featured lead, Maura, played by cisgendered Jewish male actor, Jeffrey Tambor.

Even as the performance of abject Jewishness arguably paves a humanizing way for transgender acceptance on post-network TV, the specific gendered history of Jewish bodies on-screen (always already effeminate), as well as the transgender impersonation of the lead actor, risks alienating the transgender subjects the show means to celebrate. ${ }^{20}$ As for this latter premise, it is easy enough to see Transparent's casting of its central character as troublingly appropriative, wherein "trans-face" may offer the next addition to a history of Jewish minstrel traditions (i.e. blackface, yellowface, redface, and self-othering Jewface). These performance impersonations, most popular for Jewish stage and screen performers of the early 20th century but arguably sustained ever since $^{21}$ were known to be as sympathetic in their intention as they are exploitative in practice. ${ }^{22}$ Such plays with otherness entailed the application of face make up, accompanying physical gestures, and vocal accents that often took on gender-bending characterizations for female performers. From vaudeville to minstrel circuits, the performance tradition established Jewish entertainers as comic chameleons that could play anything, anywhere. Putting on and taking off masks of more marginal figures meant performers could effectively distance themselves from the personages they parodied, however sympathetically or not. The casting of Tambor in the lead role begs this question of "trans-face" as the next of Jewish impersonations that appear especially harmful in light of his harassment. ${ }^{23}$

It is less clear, however, how Transparent works with longstanding representational tropes of Jewish men as always already womanish, and Jewish women as necessarily then more mannish (unattractive and unfeminine, and either sexually promiscuous or not available). If Jews on-screen are forever gender benders in this sense, or at the least, seen as gender non-binary and not by choice, how does a show about celebrating the possibility of actual gender diversity recuperate, reconfigure, or replace this representational script? And how does this history of Jewish male effeminacy on screen complicate the issue of Tambor's transgender impersonation as always already facilitated by the actor's Jewishness? 
Unfortunately, Tambor's actions off-camera interfered in the favorable possibilities of playing out these questions on screen. After receiving multiple prestigious awards for his performance as Maura, Tambor's trans-face role was abruptly interrupted when he was accused of sexually harassing two transwomen on set in December 2017. After the accusations against Tambor were confirmed by investigators in early 2018, Soloway fired her leading actor, issuing the public statement to The Hollwood Reporter saying she respected and admired Van Barnes and Trace Lysette for speaking out. ${ }^{24}$ As of summer 2018, Season Five has been delayed, but is proceeding without Tambor. ${ }^{25}$ I call this out to further complicate the show's altruistic efforts to draw parallels between Jewish and transgender suffering, and also to highlight Soloway's important lack of tolerance for his behavior, however difficult it must have been to proceed without the show's protagonist.

One productive takeaway of Tambor's failed trans-face is the light it sheds on the show's less than transparent conflation of ethnic and gender identity discourses, where perhaps too much is taken for granted. The casting choice of a non-transgender person in a transgender role might have remained okay for media-watch groups like GLAAD in the context of a show with record numbers of transgender actors and crew members were it not for Tambor's misconduct. However, what representational slides happen in the show's narrative conflation of Jewish and transgender stories? To what extent does this flatten discourses that are not the same, and not in the same stage of acceptance within the contemporary moment? This murky middle ground raises more questions about the ways the Season Two screendance scenes use devices of juxtaposition and circularity to depict the transgender, transgenerational possibility as a shared ring perhaps too naively.

There is no doubt that Tambor's actions break the protective circle of the Transparent family on-set and on-screen. Still, there is something else here, for me, left unresolved about the bad behavior of a Jewish father-mother figure and the question of transparency around representational stakes. In a show about loyalty no matter what and an understanding of pathologies dredged forward from the past, I can't help but wonder and worry about how Tambor's misogynist aggression comes from an ethnosexual inheritance, too, where the unchecked power abuses of Hollywood and Amazon celebrity status are mixed in with unaddressed effects of ethnic trauma. To what degree does Tambor's Jewishness, its histories of abjection in the US and also his particular experience growing up with alcoholic parents, account for but certainly not excuse some kind of transgenerational abused-to-abuser affliction? And what might it mean to posit an epigenetic scarring at the level of the body for Jewish men in strained (and trained) cycles of violence?

It is clear enough that Tambor's chauvinism off-camera fails to help the transgender liberation cause or the reparative transgenerational one, either for the Pfeffermans or the rest of us. As described by Seth Abramovitch in Hollywood Reporter, Tambor went 
"from LGBTQ folk hero to fugitive." ${ }^{26}$ And yet, I look back at the ways I experienced the celebrity's harassment like a shame on my own home and wonder what else there may be to say about Tambor's violence in the context of Jewish representation in popular culture during the age of the \#metoo movement.

I count the rising number of ousted celebrity men in Hollywood with Jewish names and ask them here at least for more transparency. Why the shmucky abuses of power? I am not alone in this critique. Writer Joseph Aaron of Chicago Jewish News wrote in the wake of Harvey Weinstein's expulsion from the Academy of Motion Picture Arts and Sciences and the slew of high-profile Jewish men that followed in fall of 2017 that "The last couple of weeks have been nothing short of a shandahfest, a shandapalooza for the Jewish people. Shandah being that great Yiddish word meaning intense shame."27 Adding emphasis, he argued, "It might be simpler for me to list all the Jewish men who have not been accused of sexual harassment than it would be to list all those Jewish men who have been." I find myself equally emphatic as Aaron then writes, "What in the hell is going on with us? Why have so many Jewish men been at the center of all this?" ${ }^{28}$

As I write, I know the consequences of my words. In a moment when Jews the world over face a dangerous resurgence of anti-Semitism, my challenge to Jewish men negotiating their own celebrity power may provoke fears in readers wondering if such a critique is "good for the Jews." ${ }^{29}$ The question lingers like an unanswered adage in cultural commentaries of American Jewishness not wanting unfavorable actions to be seen as broader ethnic phenomena. But in a show that so blatantly asks its Jewish viewers to question our own behavior in the context of generations past as a process of coming out and into more liberated versions of ourselves, Tambor's on- and off-camera character begs us to ask: What is the full range of cultural inheritances that encode our actions and experiences into scarred DNA, and how can our depictions of transgenerational memory help both access and re-pattern the fullest dimension of inherited trauma and cycles of abuse?

A different analysis of the show might focus on the slew of inappropriate and even aggressive decisions that each of the Pfefferman family member makes in excess throughout the show's four seasons. From predatory sex requests to any number of other self-serving tactics, the nuclear family appears prone to present-day manipulations played out in ways justified by the very transgenerational traumas (aka the Holocaust) underscored here. But in this essay's focus on screendance scenes, and the co-choreography of the bodily action and camera to invoke visceral instances of inclusion and exclusion, this final take on Tambor's misconduct necessarily muck up the copacetic, co-constitutive premise of the show's artful conjoining of transgender, transhistorical frames in ways that point to particular issues of internal versus external abuses. The sympathetic joys and pains aestheticized through the show's screendance scenes ultimately stand out most for their admittedly uncomplicated depictions of the family either working well together or pulled apart by external forces. Tambor's 
harassments move him from the former family bonds into the latter limitations on them, as he becomes the aggressive figure pulling the circle apart.

\section{Conclusion}

As I have tried to show, Transparent frames its central transgender coming out and all that it throws in question for the Pfefferman family through a transhistorical, transgenerational portrayal of their collective ethno-sexual past. It does so most potently through screendance sequences that emphasize a circularity of time and context, wherein dialogue stops and movement (plus costume, sound, and lighting design) takes over. It is this layered trans context that moves around and within, as opposed to merely across historical and gender boundaries that is matched by the circular movement of dancing bodies and camera. Framing this circular depiction of trans-ness as the show's key contribution to screendance scholarship, I have argued for a naming of Soloway's screendance scenes as "trans-screens" that deploy body and camera action to encircle and embrace bodies and identities in healing motion, whether through the joy of collective dancing, or the pain of lived and inherited trauma, that in a process of communal grieving, can begin to heal for present-day characters.

As the communal body moves in harmonious happiness or sadness together, the circle stays intact as choreographic motif, its characters belonging to the inside group. It is this feature of the screendance-styled scene for post-network TV that aestheticizes "edgy" and "oppositional" material to make it more digestible, and in turn more pardonable, operating on our senses in ways that engender kinesthetic empathy with the family and friends we come to know. It is this artful insertion of dance in the midst of the show's more controversial storylines that best helps viewers repeatedly embrace this family, their problems, and their transitions within the circle frame. In that transgender, transhistorical view of a Jewish family's collective coming out, however, questions remain about the ethics of representation or even impersonation, when actors are less generous, and less transparent, than their roles.

\section{Biography}

Hannah Schwadron writes and dances on Jewish themes, and is author of The Case of the Sexy Jewess: Dance, Gender, and Jewish Joke-work in US Pop Culture (OUP, 2018). Other essays appear in Liminalities, PARtake, Choreographic Practices, The Oxford Handbooks on Dance and Politics and Dance and Music, and the Dancer-Citizen. Her dance film Klasse 
(Germany, 2015), made with director Malia Bruker and a cast of middle school students, won Dance Film Association's Production Grant, and has shown at Washington Jewish Film Festival, American Dance Festival, Antimatter [Media Art], Tiny Dance Film Fest, Israelitische Töchterschule, Third Coast Dance Film Festival (Spirit of the Festival award), and ScreenDance Miami (Audience Choice award). Her second screendance Between I and Thou (Germany, 2017), has shown at Little Mexico Film Festival, Docs Wthout Borders, and Toronto Short Film Festival, and Richmond International Film Festival. She is Assistant Professor of Dance at Florida State University.

Email: HSchwadron@fsu.edu

\section{Notes}

${ }^{1}$ Post-network TV is that matrix of broadcast networks, cable channels, web outlets, and streaming media we access by now without much thought, but which is always thinking about us as it programs ever-edgier content its numbers show we want to see. After corporate firms like Viacom and Time Warner raced to catch up with the pace of cultural change in the 1980s and 90s, twenty-odd years of post-network television has evolved single-channel shows to infinite iterations made for nicheviewer devotees; smaller market segments with bigger gains. The term "post-network" was coined by Amanda D. Lotz, The Television Will Be Revolutionized.

${ }^{2}$ Nick Marx, "Expanding the Brand," 275.

${ }^{3}$ Ann Friedman, "TV's New Revolutionary."

${ }^{4}$ Ibid. According to Friedman's interview with Zackary Druker, who, along with her partner, Rhys Ernst, was hired by Soloway as a consultant to ensure the show was portraying transgender lives authentically, "There is absolutely a social-justice mission to what we do in addition to creating art...Jill's really shown herself to be such a huge ally to the community."

${ }^{5}$ Since Transparent aired in 2014, the show has won countless awards, including the 2015 Golden Globes Best Television Series and Best Performance by an Actor in a Television Series; 2015 and 2016 Primetime Emmy Awards in Outstanding Lead Actor in a Comedy Series for Jeffrey Tambor's role as Maura, Outstanding Director of a 
Comedy Series for Jill Soloway, among others; 2016 BAFTA TV award for Best International program; 2016 Screen Actors Guild Awards for Outstanding awards by a Male Actor in a Comedy Series; 2015 AFI award for TV Program of the Year; Casting Society of America award in 2016 and 2017 for Outstanding Achievement in Casting; Critics Choice Television Awards in 2015 and 2016 for Best Actor in a Comedy Series, and many more.

"Soloway's cinematographer, Jim Frohna told Indiewire that "Jill asked me to join her and the cast at rehearsals with indie filmmaking guru and consulting producer Joan Scheckel. The time spent was not about running scenes, but about exploring character, relationship and emotion - all with music and through movement. Jill or Joan would call out specific actions: 'Go to the person who you feel most connected to, or least connected to,' for example. And while I had my still camera there to document moments for possible reference, I was participating as fully as the actors were. That's a treasure for a DP. And it was fantastic." See Valentina I. Valentini, "Shooting 'Transparent."'

${ }^{7}$ lbid.

${ }^{8}$ Matt Wilstein, "Jay Duplass on 'Transparent' Without Jeffrey Tambor and His Most Devastating Role Yet."

${ }^{9}$ lbid.

${ }^{10}$ Dan Hurley, "Grandma's Experiences Leave a Mark on Your Genes."

${ }^{11}$ Rosy Simas, "We Wait in the Darkness."

${ }^{12}$ For New York Times TV critic Rachel Syme, Soloway's "exaggerated lens" mirrors Sarah's unease in marrying Tammy (Melora Hardin) through "a kind of glitterbomb of nauseating excess: the overlined lips of the chanteuse, the bouncing of the dancing crowd, the kind of sickly yellow light cast over the whole party." Such techniques help foment the feeling of "commitment-phobia" which Syme says plagues the family. Syme, "Transparent' Season 2 Premiere."

${ }^{13}$ Kyla Bills, "A Guide to Transparent Season Two's LBGT plotline." In February 1933, the Nazi Party launched an LBGT purge in Berlin. The books of the Institute were destroyed and the Institute itself closed, ending the golden era of Berlin LGBT life. Between 1933 and 1945, over 100,000 men were arrested for being homosexual. Many were sent to concentration camps, although the exact number is unknown.

${ }^{14}$ See Robert Beachy, Gay Berlin.

${ }^{15}$ Douglas Rosenberg, "Introduction," 6.

${ }^{16}$ See Erin Brannigan, "Micro-Choreographies." 
${ }^{17}$ Karen Wood, "Kinesthetic Empathy," 247. According to Wood's explication of kinesthetic empathy in screendance, the viewer's mirror neurons fire not only because of identification with the characters and content, but also because of the unique work of dance on camera. While she bemoans the lack of research on the kinesthetic experience of watching screendance, Wood confirms the rich body of scholarship on emotion elicitation in film studies, which is implicitly linked to kinesthetic empathy.

${ }^{18}$ For more on this, see John Phillips, Transgender on Screen; Joyelle Ruby Ryan, Reel Gender; and Theresa Carilli and Jane Campell, Queer Media Images.

${ }^{19}$ Such filmic representation of Jewish acculturation started arguably with the first "talkie" The Jazz Singer and has reiterated across a century of Jewish representation in Hollywood films such as Funny Girl (1968), Portnoy's Complaint (1970), and Annie Hall (1977) as serious and humorous content.

${ }^{20}$ See for instance Daniel Boyarin, Unheroic Conduct.

${ }^{21}$ See Hannah Schwadron, The Case of the Sexy Jewess.

${ }^{22}$ As Jews navigated positions of alterity, scholarship on the subject disagrees over the extent to which these race and gender impersonations engendered empathetic allegiances to other Others even as such performance practices assisted the process of assimilation. For helpful histories of this debate regarding Jewish race impersonation in live and screen performance as well as literature, see Eric Lott, Love and Theft; Michael Rogin, Blackface, White Noise; Lori Harrison-Kahan, The White Negress; and Schwadron.

${ }^{23}$ See Stacey Wilson Hunt's interview for Vulture Magazine with actress Alexandra Billings ("Davina"); producer Zackary Drucker; producer Rhys Ernst; actress Alexandra Grey ("Elizah Edwards"); director Silas Howard; writer Ali Liebegott; actress Trace Lysette ("Shea"); and writer Our Lady J, on how the series has changed the way television tells trans stories, the hopefulness they now feel for trans children, and why they disagree on how important it is to cast trans people in transgender roles. Stacey Wilson Hunt, "How TV is Breaking Into Us."

${ }^{24}$ See Lesley Goldberg, "Jeffrey Tambor Officially Dropped." In her official statement Soloway said, "We are grateful to the many trans people who have supported our vision for Transparent since its inception and remain heartbroken about the pain and mistrust their experience has generated in our community. We are taking definitive action to ensure our workplace respects the safety and dignity of every individual, and are taking steps to heal as a family."

${ }^{25}$ Clarisse Loughrey, "Transparent season 5 delayed." 
${ }^{26}$ Seth Abramovitch, "'Lines Got Blurred.'”

27 Joseph Aaron, "Anti-Bris Jewish Men." Aaron bemoans a growing list as of fall 2017 of Jewish men in Hollywood called out for sexual abuse. He writes, "TV commentator Mark Halperin and magazine writer Leon Wieseltier and director James Toback and producer Brett Ratner and head of Amazon studios Roy Price and actors Dustin Hoffman and Richard Dreyfuss and Jeremy Piven and Jeffrey Tambor, who plays the head of a Jewish family in his series 'Transparent,' which last season was largely set in Israel, and NPR news chief Michael Oreskes and comedian Louis CK, whose grandfather was born Jewish and whose father converted to Orthodox Judaism. I could name another ten. Indeed, even though Jews are a minority, they are a majority of those recently accused of being sexual harassers."

${ }^{28}$ Ibid.

${ }^{29}$ See the same line of questioning in Grace Overbeke, "The Case of The Sexy Jewess," a review of my book of the same title.

\section{References}

Aaron, Joseph. “Anti-Bris Jewish Men." Chicago Jewish News. Posted 16 Nov 2017. https://www.chicagojewishnews.com/2017/11/anti-bris-jewish-men/

Abramovitch, Seth. "'Lines Got Blurred': Jeffrey Tambor and an Up-Close Look at Harassment Claims on 'Transparent.'" Hollywood Reporter. Posted on 7 May 2018. https://www.hollywoodreporter.com/features/lines-got-blurred-jeffrey-tambor-an-upclose-look-at-harassment-claims-transparent-1108939

Annie Hall. Directed by Woody Allen. Los Angeles: Jack Rollins \& Charles H. Joffe Productions, 1977.

Beachy, Robert. Gay Berlin: Birthplace of Modern Identity. New York City: Vintage Books, 2014.

Bench, Harmony. "Screendance: Inscribing the Ephemeral Image by Douglas Rosenberg, and Dancefilm: Choreography and the Moving Image by Erin Brannigan." Dance Research Journal 45.2 (2013): 132-138. https://doi.org/10.1017/S0149767713000053

Bills, Kyla. "A Guide to Transparent Season Two's LGBT plotline" Posted 12 December 2015. https://milk.xyz/articles/a-guide-to-transparent-season-twos-historical-lgbtplotline/ 
Boyarin, Daniel. Unheroic Conduct: The Rise of Heterosexuality and the Invention of the Jewish Man. Berkeley: University of Califonia Press, 1997.

Brannigan, Erin. "Micro-Choreographies: The Close-Up in Dancefilm." International Journal of Performance Arts and Digital Media 5.2-3 (2009): 121-139.

https://doi.org/10.1386/padm.5.2-3.121/1

Carilli, Theresa and Jane Campell, eds. Queer Media Images: LGBT Perspectives. Maryland: Lexington Books, 2013.

Fiddler on the Roof. Directed by Norman Jewison. Los Angeles: The Mirisch Production Company, 1971.

Friedman, Ann. "TV's New Revolutionary: How Jill Soloway Is Singlehandedly Changing the Game." Posted on 27 Oct 2015. https://www.marieclaire.com/culture/a16338/jillsoloway-profile/

Funny Girl. Directed by William Wyler. Los Angeles: Columbia Pictures Corporation, 1968.

Goldberg, Lesley. "Jeffrey Tambor Officially Dropped From 'Transparent' in Wake of Harassment Claims." The Hollywood Reporter. Posted 15 February, 2018.

https://www.hollywoodreporter.com/live-feed/jeffrey-tambor-officially-firedtransparent-wake-harassment-claims-1085236

Hager, Jenna Bush. "Jeffrey Tambor \& 'Transparent' Cast: The World Has Changed." TODAY. Posted 25 June, 2015. https://www.youtube.com/watch?v=DPXU8TIM9_U

Harrison-Kahan, Lori. The White Negress: Literature, Minstrelsy, and the Black-Jewish Imaginary. Piscataway: Rutgers University Press, 2011.

Hunt, Stacey Wilson. "How TV is Breaking Into Us." Vulture Magazine. Posted 28 September 2016.

Hurley, Dan. "Grandma's Experiences Leave a Mark on Your Genes." Discover Magazine. Posted 25 June 2015. http://discovermagazine.com/2013/may/13-grandmasexperiences-leave-epigenetic-mark-on-your-genes

The Jazz Singer. Directed by Alan Crosland. Los Angeles: Warner Brothers, 1927. Lott, Eric. Love and Theft: Blackface Minstrelsy and the American Working Class. New York City: Oxford University Press, 1993.

Lotz, Amanda D. The Television Will Be Revolutionized. New York City: New York University Press, 2007. 
Loughrey, Clarisse. "Transparent Season 5 Delayed in Wake of Jeffrey Tambor allegations" Independent. Posted 8 March 2018. https://www.independent.co.uk/artsentertainment/tv/news/transparent-season-5-delayed-2019-jeffrey-tambor-quitssexual-harassment-allegations-a8245481.html

Marx, Nick. "Expanding the Brand: Race, Gender, and the Post-Politics of Representation on Comedy Central." Television \& New Media 17. 3 (2016): 275.

Overbeke, Grace Kessler. "The Case of The Sexy Jewess: Dance, Gender, and Joke-Work in U.S. Pop Culture by Hannah Schwadron (review)." Theater Journal 70.2 (2018): 265267. https://doi.org/10.1353/tj.2018.0046

Phillips, John. Transgender on Screen. London: Palgrave Macmillian, 2006. https://doi.org/10.1057/9780230596337

Portnoys Complaint. Directed by Ernest Lehman. Los Angeles: Chenault Productions, 1972.

Rogin, Michael. Blackface, White Noise: Jewish Immigrants in the Hollywood Melting Pot. Berkeley: University of California Press, 1998.

Rosenberg, Douglas. "Introduction." In The Oxford Handbook of Screendance Studies. Ed. Douglas Rosenberg. New York City: Oxford University Press, 2016. 1-22.

https://doi.org/10.1093/oxfordhb/9780199981601.013.37

Ryan, Joelle Ruby. Reel Gender: Examining the Politics of Trans Images In Film And Media. Ohio: Bowling Green State University Popular Press, 2009.

Schwadron, Hannah. The Case of the Sexy Jewess: Dance, Gender, and Jewish Joke-work in US Pop Culture. Oxford University Press, 2018.

Schindler's List. Directed by Steven Spielberg, Los Angeles: Universal Pictures, 1993.

Simas, Rosy. "My Making of We Wait in the Darkness." Dance Research Journal 48.1 (2016): 29-32. https://doi.org/10.1017/S0149767716000073

Syme, Rachel. "Transparent' Season 2 Premiere: Hava Nagila and Kina Hora." The New York Times. Posted 11 Dec 2015.

https://www.nytimes.com/2015/12/10/arts/television/transparent-season-2-premierereview.html

"Transparent: Cast Members Talk Season 4, Character Dynamics \& Much More." Entertainment Weekly. Posted on 24 Oct 2016.

https://www.youtube.com/watch?v=h0ixqGJlvTY

Valentini, Valentina I. "Shooting 'Transparent': From Rehearsal to Lenses to Intimate Family Drama." IndieWire. Posted on 7 Oct 2014. 
https://www.indiewire.com/2014/10/shooting-transparent-from-rehearsal-to-lensesto-intimate-family-drama-69326/

Wilstein, Matt. "Jay Duplass on 'Transparent' Without Jeffrey Tambor and His Most Devastating Role Yet." Posted on 23 March 2018. https://www.thedailybeast.com/jayduplass-on-transparent-without-jeffrey-tambor-and-his-most-devastating-role-yet

Wood, Karen. "Kinesthetic Empathy: Conditions for Viewing." In The Oxford Handbook of Screendance Studies. Ed. Douglas Rosenberg. New York City: Oxford University Press, 2016. 245-262. 